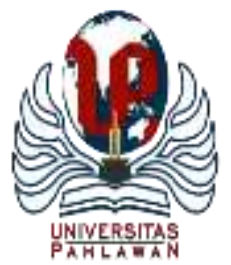

Edukatif : Jurnal Ilmu Pendidikan Volume 4 Nomor 1 Tahun 2022 Halm 53 - 62 EDUKATIF: JURNAL ILMU PENDIDIKAN

Research \& Learning in Education

https://edukatif.org/index.php/edukatif/index

\title{
Strategi Pendidikan Karakter Integritas Berbasis Masyarakat di Satuan Pendidikan Dasar
}

\author{
Lisa Retnasari $^{1 凶}$, Sumaryati ${ }^{2}$ \\ Universitas Ahmad Dahlan, Indonesia ${ }^{1}$ \\ Universitas Ahmad Dahlan, Indonesia ${ }^{2}$ \\ E-mail : $\underline{\text { lisa.retnasari@pgsd.uad.ac.id }}{ }^{1}, \underline{\text { sumaryati@ppkn.uad.ac.id }}^{2}$
}

\begin{abstract}
Abstrak
Di era globalisasi penguatan pendidikan karakter menjadi pondasi untuk melahirkan generasi-generasi muda yang berintegritas didukung dengan masyarakat sebagai basis penguatan pendidikan karakter. Penelitian yang dilakuakan bertujuan mendeskripsikan strategi satuan satuan pendidikan dasar di Kepanewon Galur Kulon Progo (SDN Brosot dan SD Muhammadiyah Wonopeti 1) dalam melakukan penguatan pendidikan karakter integritas berbasis masyarakat. Metode penelitian yang digunakan yaitu kualitatif deskriptif. Subjek penelitian terdiri dari kepala sekolah, dan guru kelas. Pengumpulan data dilakukan melalui observasi, FGD dan dokumentasi. Analisis data dilakukan dengan triangulasi data. Hasil penelitian mengenai strategi dalam pendidikan karakter integritas berbasis masyarakat di satuan pendidikan dasar Kepanewon Galur Kulon Progo yaitu dilakukan melalui pertama, merumuskan program pendidikan karakter berbasis masyarakat. Adapun tahapan perumusannya yaitu sosialisasi, implementasi penguatan pendidikan karakter, evaluasi dan rencana tindak lanjut. Kedua, pelibatan lingkungan sebagai sumber penguatan pendidikan karakter integritas. Proses kegiatannya dilakukan melaui kolaborasi dengan wali murid dan alumni sebagai tokoh masyarakat, penggunaan buku pantauan kegiatan nilai-nilai karakter, mengunjungi pabrik industri, pondok pesantren, pasar, bank sampah dan komunitas lainnya. Hal ini memberikan dampak positif dalam rangka menumbuh kembangkan nilai kejujuran, tanggung jawab dan cinta kebenaran pada peserta didik.
\end{abstract}

Kata Kunci: Karakter Integritas, Berbasis Mayarakat, Satuan Pendidikan Dasar.

\begin{abstract}
In the era of globalization, strengthening character education is the foundation for giving birth to young generations with integrity, supported by the community as the basis for strengthening character education. This research aims to describe the strategy of the basic education units in Kepanewon Galur Kulon Progo (SDN Brosot and SD Muhammadiyah Wonopeti 1) based on the community. The research method used is descriptive qualitative. The research subjects consisted of principals, and classroom teachers. Data were collected through observation, FGD, and documentation. Data analysis was done by data triangulation. The results of the research on strategies in community-based integrity character education in the Kepanewon Galur Kulon Progo basic education unit were carried out starting from the first, formulating a community-based character education program. The stages of its formulation are socialization, implementation of strengthening character education, evaluation, and follow-up plans. Second, environmental involvement is a source of strengthening integrity character education. This is done through collaboration with parents and alumni as community leaders, use of character values activity watch books, visits to industrial factories, Islamic boarding schools, markets, waste banks, and other communities. This has a positive impact to foster the value of honesty, responsibility, and love of truth in students.
\end{abstract}

Keywords: Integrity Character, Community Based, Elementary School.

Copyright (c) 2022 Lisa Retnasari, Sumaryati

$\checkmark$ Corresponding author

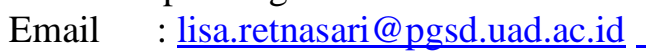

DOI : https://doi.org/10.31004/edukatif.v4i1.1739

ISSN 2656-8063 (Media Cetak)

ISSN 2656-8071 (Media Online) 
DOI: https://doi.org/10.31004/edukatif.v4i1.1739

\section{PENDAHULUAN}

Perkembangan dunia kini begitu cepat memasuki era globalisasi yang seakan tidak ada batas geografis dan menembus ruang serta waktu. Termasuk perubahan dan masalah-masalah moral yang terjadi di Indonesia seperti ketamakan, ketidakjujuran, kekerasan, pengabaian diri, penyalahgunaan narkoba dan tindakan bunuh diri. Hal ini menjadi perhatian penting dalam dunia pendidikan yang menekankan penguatan pendidikan karakter sejak usia dini. Mengingat tujuan dari sistem pendidikan nasional ialah menyiapkan generasi muda yang beriman, betaqwa, cerdas dan berkarakter guna keberlangsungan kehidupan bermasyarakat dan berbangsa (Kurniawan \& Kusumawardana , 2020). Sekolah bukan hanya menjadi tempat bertemuanya guru dan peserta didik dalam rangka memperkaya ilmu pengetahuan. Sekolah menjadi upaya dan proses pembelajaran yang berorientasi pada nialai (Fraenkel, 1977). Sekolah memiliki peran penting dalam menyelenggarakan pendidikan karakter, dimulai dari pondasi awal pendidikan yaitu pendidikan sekolah dasar. Sekolah merupakan lembaga yang dipandang sebagai wadah memersiapkan peserta didik secara baik sebagai agen moral dan intelegensi (Wuryandani, Maftuh, Sapriya, \& Budimansyah, 2014). Nilai karakter tersebut seperti mandiri, religius, gotong-royong, integritas, dan nasionalis. Kelima nilai utama tersebut merupakan nilai fundamental dalam program penguatan pendidikan karakter (PPK). Penguatan Pendidikan Karakter (PPK) sebagai upaya dalam menghadapi tantangan masa depan yang semakin kompleks. PPK menjadi butir Nawacita yang tertera pada Gerakan Nasional Revolusi Mental (GNRM) (PPK, 2017). Dengan kata lain, sekolah memiliki tanggung jawab untuk menumbukembangkan nilai-nilai karakter tersebut melalui olah hati, olah rasa, olah pikir dan olah raga serta kerja sama dengan semua pihak terkait.

Salah satu nilai karakter yang perlu dikembangkan yaitu karakter integritas. Nilai karakter integritas menjadi hal yang penting untuk dimiliki oleh seseorang manusia. Karena karakter integritas merupakan nilai utama yang mendasari cara berpikir, bersikap dan berperilaku amanah pada nilai sosial dan moral lainnya (Anshori, 2017). Indiktor terjadinya pelunturan terhadap karakter integritas yaitu maraknya kasus korupsi, ujaran kebencian, eksklusif atas nama SARA dan tindak penyimpangan moral lainnya. Kalau dianalisis koruptor dapat digolongkan sebagai manusia yang cerdas secara intelegensi, namun belum tentu berkarakter berdasarkan apa yang telah dilakukannya. Dalam hal ini melakukan tindak criminal mencuri uang rakyat. Cerdas dan berkarakter bukanlah dua kata yang sama. Namun mendidik karakter masyarakat setara dengan pendidikan intelegensi, mendidik kesopanan setara dengan literasi, mendidik kebajikan setara dengan pendidikan ilmu pengetahuan (Lickona, 1991). Hal ini memberi makna dengan adanya intelegensi memberikan dampak kebermanfaatan bagi diri dan masyarakatnya. Pembentukan karakter di sekolah nantinya akan dikembalikan lagi ke masyarakat Penguatan nilai karakter integritas meliputi sikap dan perilaku yang didasarkan agar seseorang tersebut menjadikan dirinya sebagai manusia yang dapat dipercaya baik perkataan, perbuatan maupun pekerjaannya serta secara komitmen pada nilai-nilai kemanusian (PPK, 2017). Adapun sub nilai dari karakter integritas yaitu kejujuran, cinta pada kebenaran, anti korupsi, keadilan, tanggung jawab, keteladanan dan menghargai martabat individu (Komara, 2018). Indonesia sebagai suatu bangsa tentu tidak ingin kehilangan karakter atau jati dirinya. Terutama nilai kejujuran, dalam tanatan masayarakat nilai kejujuran merupakan alat ukur untuk melihat kebaiaj seseorang. Kejujuran mendasari bagaimana mencipatakan kehidupan yang harmonis di lingkungan keluragraa, masyarakat, bangsa dan negara (Zubaedi, 2011).

Dekandensi moral tidak hanya menjadi masalah dan tanggung jawab sekolah. Tri pusat pendidikan yaitu keluaraga, sekolah dan masyarakat juga memiliki kontribusi dalam meminimalisir kasus-kasus tersebut. Pemerintah dengan kebijakan PPK serta penyempurnaan Kurikulum 2013 sebagai komitmen dalam menanamkan, memperkuat dan membiasakan nilai-nilai karakter baik pada peserta didik sedini mungkin. Hal ini merupakan upaya menjaga eksistensi sebagai bangsa yang berkeadaban dan berkarakter dilakukan secara bersinergi mulai dari pemerintah maupun masyarakat. Termasuk dalam penyiapan masyarakat yang cerdas 
dan baik (smart and good citizen) sejak dini guna penyiapan estafet kepemimpinan yang berintegritas (Auliyairrahmah, Djazilan, Nafiah, \& Hartatik, 2021). Dalam hal ini sekolah memainkan peran untuk menjabarkan kebijakan dalam sebuah tindakan nyata yang melibatkan peserta didik dalam mengembangkan aspek kognitif, afektif dan psikomotorik agar berkembang dengan baik Sekolah sebagai miniatur kehidupan sosial peserta didik dalam mengembangkan nilai karakter (Widodo, 2019). Oleh karena itu, sekolah perlu membangun budaya karakter melalui ekosistem yang baik. Keberhasilan jangka panjang tentang pendidikan karakter bergantung pada kekuatan di luar sekolah. Hal ini melihat keluraga dan komunitas masyarakat bergabung dalam usaha bersama memberikan kebutuhan peserta didik dalam mengembangkan karakter mereka. Kolaborasi yang dilakukan antara sekolah dengan Lembaga, LSM, komunitas dan sumber lingkungan lainnya merupakan pengauatan karakter berbasis masyarakat (Yetri \& Firdaos, 2017).

Beberapa penelitian tedahulu mengenai penguatan pendidikan karakter berbasis masyarakat antara lain: 1) Penelitian (Hutabarat \& Sumantri , 2019) tenatang implementasi penguatan pendidikan karakter berbasis masyarakat dalam meningkatkan kesadaran sikap peduli sosial peserta didik menghasilkan bahwa keikutsertaan masyarakat dalam menanamkan karakter peduli sosial pada peserta didik sangat berkontribusi khusunya aktualisasi nilai religius, bela negara dan griya estetika. Masyarakat sebaga wadah aktualisasi karakter peduli sosial. 2) Penelitian yang dilakukan (Yetri \& Firdaos, 2017) mengenai PPK berbasis masyarakat pada sekolah menengah pertama negeri (SMPN) di Kab. Tulang Bawang Provinsi Lampung hasilnya menunjukan bahwa perlu kemampuan sekolah dalam mengkolaborasi program pendidikan karakter yang nantinya bekerja sama dengan masyarakat. Selain itu secara umum masyarakat antusias dan memiliki kemauan untuk dapat berparisipasi aktif dalam mensukseskan program PPK. 3) Penelitian yang dilakukan oleh (Ali, Kristiawan, \& Fitriani, 2021) mengenai implementasi pendidikan karakter berbasis budaya sekolah yang menghasilkan bahwa pendidikan karakter merupakan senjata ampuh dalam merealisasikan fungsi dan tujuan pendidikan nasional. Berdasarkan penelitian terdahulu penguatan pendidikan karakter perlu didukung oleh pemangku kebijakan baik pemerintah maupun swasta bekerja sama dengan sekolah orang tua dan masyarakat guna mencegah dekadensi moral sebagai dampak globalisasi.

Penelitian terdahulu mengenai penguatan pendidikan karakter masih membahas secara umum nilai-nilai karakter yang dikembangkan atau nilai-nilai karakter yang cenderung monoton, masih belum banyak yang membahas nilai karakter integritas. Karakter integritas merupakan benteng dalam menyiapkan anak-anak muda anti korupsi. Sesuai dengan maknanya integritas berartu jujur dan prinsip moral di dalam diri seseorang yang dilakukan secara menyeluruh dan konsisten (Ulya \& Anisah, 2021). Selain itu juga, subjek dari penelitian penguatan pendidikan karakter berbasis masyarakat cenderung SMP dan SMA. Padahal dalam buku pedoman PPK kemendikbud menjadi kewajiban semuan satuan pendidikan dalam menyelenggarakan PPK berbasis masyarakat secara utuh yang merupakan sekolah pelaksana kebijakan penguatan pendidikan karakter salah satunya berbasis masyarakat. Fokus penelitian ini akan menggali dan mendeskripsikan secara komperhensif strategi penguatan pendidikan karakter integritas di satuan pendidikan SDN Brosot dan SD Muhammadiyah Wonopeti 1 merupakan satuan pendidikan sekolah dasar di Kepanewonan Galur Kulon Progo. Sekolah-sekolah tersebut merupakan sekolah negeri dan swasta yang sudah terakreditasi A, memiliki kepercayaan dari masyarakat terbukti dengan jumlah siswa rata-rata 200 peserta didik, dan menjadi sekolah unggulan dalam kegiatan adiwiyata. Terkait peguatan pendidikan karakternya di sekolah tersebut masih ada beberapa anggapan orang tua wali bahwa guru atau sekolahlah yang memiliki tugas besar dalam menanamkan nilai karakter Selama masa pandemi covid 19 tentu diperlukan kerja sama yang baik dalam mendidik karakter integritas pada diri peserta didik baik antara sekolah, komite sekolah, orang tua dan komunitas. Oleh karena itu artikel ini menfokuskan pada bagaman strategi atau cara penguatan pendidikan karakter integritas berbasis masyarakat di satuan pendidikan Kepanewonan Galur Kecamtan Kulon Progo?. 
Strategi Pendidikan Karakter Integritas Berbasis Masyarakat di Satuan Pendidikan Dasar - Lisa Retnasari, Sumaryati

DOI: https://doi.org/10.31004/edukatif.v4i1.1739

\section{METODE PENELITIAN}

Penelitian merupakan penelitian deskriptif dengan pendekatan kualitatif. Penelitian deskriptif kualitatif yaitu penelitian yang menyajikan data dengan menggunakan kata-kata dan mendeskripsikannya (Moleong, 2007). Subjek penelitian ini adalah kepala sekolah, wakil kepala sekolah, dan guru kelas di SDN Brosot dan SD Muhammadiyah Wonopeti 1 Galur menggunakan purposive sampling. Objek penelitian adalah strategi pendidikan karakter integritas berbasis masyarakat yang dilakukan dikedua sekolah tersebut. Pengambilan data menggunakan observasi, FGD dan dokumentasi. Tahapan dilakukan mulai dari koordinasi tim penelit, melalukan perisinan dan finalisasi instrument penelitian. Pada pelaksanaan dilakukan secara FGD luring dan daring di kedua sekolah tersebut dan dilakukan perekeman hasil wawancara melalui recording dan kuesioner dengan google form. Analisis data menggunakan model interaktif Miles dan Huberman yaitu pengumpulan data, reduksi data, penyajian data dan penarikan kesimpulan.

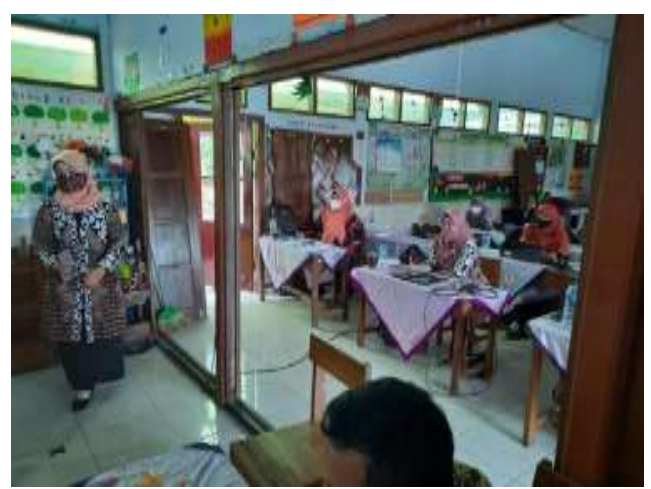

Gambar 1 FGD dengan SDN Brosot

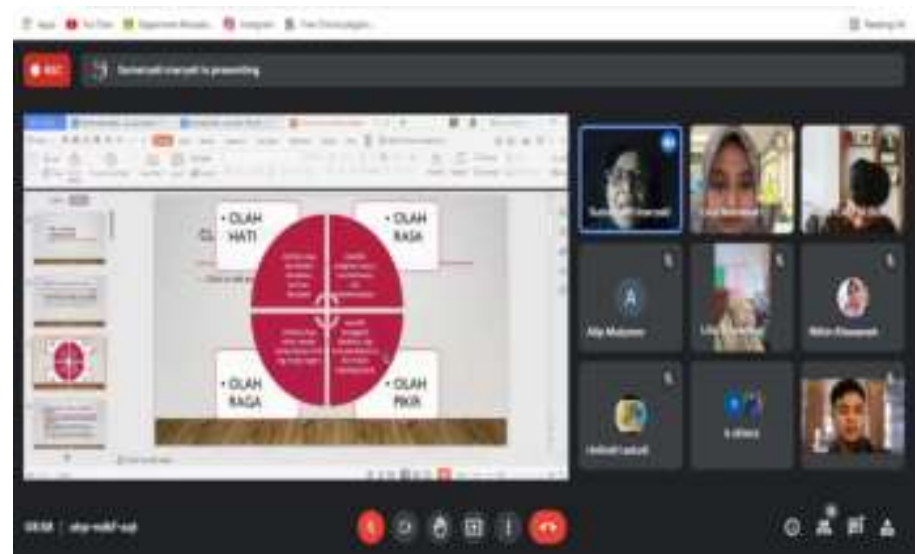

Gambar 2 FGD dengan SD Muhammadiyah Wonopeti 1

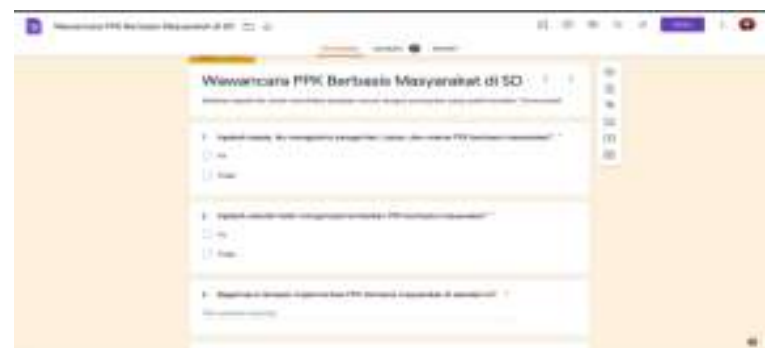

Gambaer 3 Kuisioner PPK Berbasis Masyarakat 
Strategi Pendidikan Karakter Integritas Berbasis Masyarakat di Satuan Pendidikan Dasar - Lisa Retnasari, Sumaryati

DOI: https://doi.org/10.31004/edukatif.v4i1.1739

\section{HASIL DAN PEMBAHASAN PENELITIAN}

Berdasarkan tujuan penelitian yang dilaksanakan berikut hasil dan pembahasan mengenai strategi pendidikan karakter integritas berbasis sekolah yang dilakukan di satuan pendidikan sekolah dasar Kepanewon Galur Kulon Progro yaitu SDN Brosot dan SD Muhammadiyah Wonepeti 1 yang dilakukan mulai merumuskan program pendidikan karakter berbasis masyarakat dan pelibatan lingkungan sebagai sumber penguatan karakter integritas pada diri peserta didik.

\section{Merumuskan Program Pendidikan Karakter Berbasis Masyarakat}

Berdasarkan hasil wawancara dengan guru sekolah dasar di kecamatan Galur Kulon Progo menyatakan bahwa guru sudah memahami pendidikan karakter bebasis masyarakat. Hal ini baik kepala sekolah, guru, tenaga penddikan dan komite sekolah memahami konsep, kerangka dan metode pelaksanaan pendidikan karakter berbasis masyarakat. Tentu ini menjadi pendorong terciptanya penguatan pendidikan karakter berbasis masyarakat secara masif dan terstruktur. Pada Abad 21 generasi yang harus disiapkan adalah mereka yang memiliki kompetensi life career skills, learning and innovation skills, information, media and techologi skills (National Education Sociaty). Hal ini menjadikan pendidikan karakter menjadi komponen penting untuk menyiapkan life career skills secara khusus character building. Sekolah berperan dalam sebagai wahana dalam menanamkan nilai-nilai karakter positif. Sekolah hadir tidak hanya menjadi tempat untuk belajar saja namun terjadi proses pendidikan yang dilakukan pendidik terhadap peserta didik agar memiliki nilai luhur dan berbudi pekerti baik (Kurniawan M. I., 2015). Termasuk didalamnya dalam membelajarkan nilai inegritas pendidikan anti korupsi, berkata jujur, bertanggung jawab, mencintai kebenaran dan menghargai martabat manusia.

Sekolah dapat melaksanakan penguatan pendidikan karakter berbasis masyarakat dengan berbagai tahapan. Seperti yang dilakukan di satuan pendidikan dasar kecamatan Galur Kulon Progo yang pertama yaitu dimulai dari sosialisasi PPK secara nasional. Seperti yang disampaikan pada hasil FGD dengan guru di satuan pendidikan di kecamatan Galur Kulon Progo yaitu pertama, menyampaikan bahwa sosialisasi PPK dilakukan secara berjenjang mulai dari kepala sekolah, perwakilan guru, dan komite sekolah untuk mengikuti sosialisasi yang dilakukan oleh kementerian pendidikan terkait penyelenggaran penguatan pendidikan karakter di satuan pendidikan sekolah dasar. Selanjutnya sosialisasi dilakukan di lingkungan sekolah kepada guru lainnya dan menyampaikan kebijakan penguatan pendidikan karakter kepada wali murid. Semua pihak menjadi memahami nilai-nilai karakter utama yang harus dikembangkan pada diri peserta didik, sehingga harapannya memahami dan mendukung program penguatan pendidikan karakter tersebut. Penanggung jawab dalam program dan kegiatan PPK berbasis masyarakat adalah kepala sekolah (PPK, 2017).

Tahap yang kedua yaitu mengintegrasi lima nilai utama yaitu religius, nasionalis, mandiri, gotong royong dan integritas terintegrasi pada proses pembelajaran baik intrakurikuler maupun kokurikuler. Selain itu juga dilakukan melalui budaya sekolah yang menjadi kekhasan atau branding dari sekolah tersebut. Seperti SDN Brosot sebagai sekolah dengan branding sehati (sehat, hijau dan kreatif). Kegiatan PPK berbasis budaya sekolah yang dimilikiya pun beraneka ragam kegiatan seperti senyum, sapa, salam dan kegiatan ekstrakurikuler yang bervariasi seperti pramuka, membatik, tari dan musik dengan berbagai kejuaraan yang diraih. SD Muhammadiyah Wonopeti juga membranding menjadi sekolah yang dengan memiliki berbagai kultur sekolah yang mendorong penguatan pendidikan karakter lima nilai utama. Selain itu juga penguatan pendidikan karakter dengan menjalin kolaborasi dengan pihak luar sekolah seperti Lembaga, LSM, pabrik industri dan peran tokoh masyarakat yang sudah dilakukan oleh kedua sekolah dasar tersebut. Satuan pendidikan sekolah dasar tentu membuka diri dari kemungkinan melaksanakan kerja sama dengan berbagai lembaga, komunitas, dan masyarakat lain di luar lingkungan sekolah. Hal ini sejalan dengan (PPK, 2017) menyatakan bahwa sekolah tidak dapat melaksanakan visi-misinya tanpa kolaborasi dengan publik. 
Tahap ketiga yaitu evaluasi yang dilakukan melalui rapat antara pihak sekolah dan komite sekolah. Pembahasan evaluasi mengenai kesesuaian program dengan keberhasilan pengimplementasian pendidikan karakter pada diri peserta didik. Koordinasi juga pernah dilakukan secara insidental antara pihak sekolah dengan komite sekolah apabila terjadi kasus penyimpangan pada peserta didik. Hal ini dilakukan sebagai catatan untuk rencana tindak lanjut. Dari hasil evaluasi dan RTL berbasis masyarakat dilanjut degan pemahansan dalam rapat koordinasi dewan pendidik komite dan perwakilan kelas. Yang menjadi point penting segala tahapan yang telah dibuat menjadiakn fokus kolaborasi dangan komunitas diperuntukan untuk peserta didik (PPK, 2017).

\section{Pelibatan Lingkungan Sebagai Sumber Penguatan Pendidikan Karakter Integritas}

Satuan pendidikan dasar di Kecamatan Galur Kulon Progo memanfaatkan potensi lingkungan sebagai sumber pendidikan karakter integritas. Hal ini tercermin pada kegiatan yang dilakukan SDN Brosot yaitu melalui kolaborasi dengan alumni, wali murid, puskesmas, industri, bank sampah, pabrik tahu, pabrik jamu, sentra batik, kantor kecamatan, bank, pasar, pondok pesesantern dan lain sebagainya. Selain itu pula dengan menata lingkungan sekolah sehingga dapat dimanfaatkan sebagai sumber penguatan pendidikan karakter.

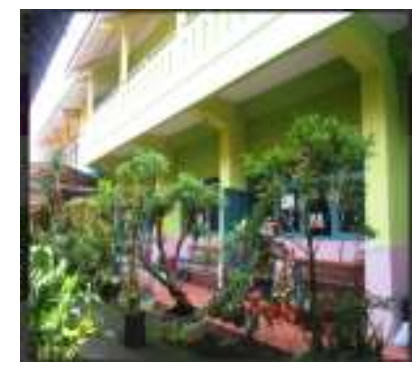

Gambar 4 Taman yang dibuat dengan kerja sama orang tua

Gambar tersebut merupakan hasil penataan taman di SDN Brosot yang dilakukan secara kerja sama dengan peserta didik dan orang tua wali. Dimana kerja sama dilakukan dengan menyumbangkan tanaman di rumah untuk dapat di rawat oleh peserta didik di sekolah sebagai wujud tanggung jawab akan apa yang dia miliki. Selain itu juga dengan pengelolaan sampah yang mengedeoankan eco enzim menjadi program PPK di SD N Brosot.

SD Muhammadiyan Woniopeti 1 selain melakukan kunjungan di sentral batik, industri bakpia, pasar, bank dan pondok pesantren juga secara khusus mengembangkan buku panduan penguatan pendidikan karakter yang diberi judul peantauan kegiatan penguatan nilai-nilai siswa. Hal tersebut tentu sebagai upaya mewujudkan tumbuhnya budi pekerti, pikiran dan tubuh anak (Dewantara, 2011). Selain itu sebagai wujud menyiapkan warga negara yang taqwa kepada Tuhan Yang Maha Esa, akhak mulia, mandiri, demokratis dan bertanggung jawab sesuai amanah UU Nomor 20 tahun 2003. Selain itu juga kolaborasi dengan tokoh masyarakat seperti ulama atau ustad dalam menghidupakan kegiatan masjid di sekolah tersebut dengan kegiatan shalat dhuha, shalat dhuhur berjamaah dan shalat jumat berjamaah.

Dari hasil penuturan guru-guru sekolah tersebut langkah kegiatan kolaborasi dengan wali murid maupun alumini dalam penguatan pendidikan karakter integritas yaitu penyesuaian tema pada pembelajaran tematik peserta didik. Apabila proses pembelajaran sedang membahas tema menaati aturan salah satunya aturan lalu lintas, yang pernah dilakukan SDN Brosot yaitu menghadirkan wali murid yang berprofesi sebagai polisi untuk menjelaskan materi secara ringan mengenai tertib berlalu lintas. Adapula membahas mengenai cara hidup sehat dengan bermitra wali murid atau alumni dengan latar belakang ahli kesehatan maupun Puskesmas. Hal ini sebagai upaya menumbuh kembangkan karakter integritas baik berupa tanggung jawab terhadap keselamatan diri, tanggung jawab terhadap menjaga kesehatan, dan menumbuhkan nilai kejujuran. 
Tanggung jawab diperlukan gina menjadi amal yang berani memiliki kreativitas dan mandiri dalam menyelesaikan tugasnya (Suyadi, 2013). Selanjutnya peserta didik juga bisa meneladani dari polisi, dokter atau petugas kesehatan lainnya dalam melakukan tugasnya dengan baik. Mencerminkan konseptual karakter yang dusebut moral knowing, moral feeling dan moral action dari rangkaian kegiatan yang dilakulakan (Lickona, 1991). Ketiga hal tersebut sebagai cerminan nilai baik terhadap Tuhan YME, lingkungan, bangsa dan terhadap diri sendiri. Namun ada kendala dalam peran orang tua yang ditemukan dari hasil wawancara dengan guru SDN Brosot bahwa masih adanya anggapan beberapa wali murid bahwa pendidikan karakter merupakan peran atau tugas sekolah saja.

Kemudian di SD Muhammadiyah Wonopeti 1 selama masa pandemi covid 19 dalam menanamkan karakter integritas pada anak dilakukan melalui buku pantauan keggiatan nilai-nilai karakter peserta didik.

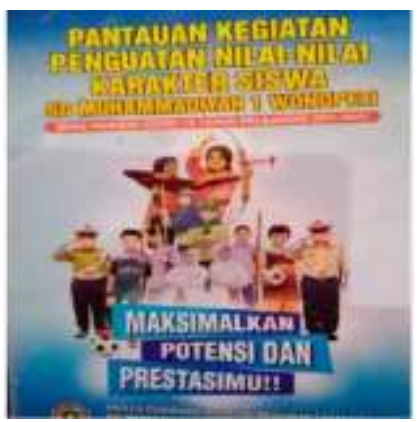

Gambar 5. Buku Pantauak Kegiatan PPK SD Muhammadiyah Wonopeti 1

Buku tersebut dibuat oleh SD Muhammadiyah Wonopeti 1 mulai dari membuat sampul, subtansi, kegiatan dan melalukan editing dengan pertimbangan dari komite sekolah. Adapun bagian isi dari buku tersebut terkait jadwal peribadahan secara mandiri di rumah dan kegiatan membantu orang tua selama pandemi covid 19. Secara teknisnya di dalam melakukan ibadah peserta didik berhak mencentang setiap selesai melaksanakan shalat atau ibadah lainnya. Hal ini menumbuh kembangkan karakter integritas yaitu berupa kejujuran, tanggung jawab, dan cinta akan kebenaran. Tidak hanya beribadah saja yang dituliskan namun juga membantu orang tua dirumah seperti merapikan tempat tidur, menyiram tanaman, menyapu dan lain sebagainya. Harapannya dengan adanya pengunaan buku pantauan kegiatan mampu melahirkan habituasi atau pembiasaan nilai-nilai karakter integritas pada diri peserta didik. Adanya pelilaku yang membuat diri agar dapat selalu dipercaya, dan setia pada nilai kemanusia dan moral termasuk nilai kejujuran dan bertangung jawab (Sriwilujeng, 2017).

Orang tua dalam buku pantau kegiatan nilai-nilai karakter berperan untuk membimbing dan memantau anak berkegiatan nilai-nilai moral sesuai buku tersebut. Selanjutnya evaluasi dilakukan dengan cara guru mengkontrol buku kegiatan penguatan nilai dan memberikan feedback berupa saran, apresiasi, dan punishment apabila peserta didik tidak melaksanakannya dengan baik. Serta menjalin komunikasi melalui whatsapp, zoom dan platform lainnya dengan orang tua wali selama proses penggunaan buku tersebut. Namun dalam hal ini masih ada kendala yang ditemukan seperti masih adanaya orang tua yang tidak dapat mengikuti rapat koordinasi melali zoom meeting dikarenakan lemahnya konektivitas, kuota dan perangkat komunikasi yang kurang mendukung. Selain itu, kesibukan wali murid yang beraneka ragam membuat kurangnya pengawasan, mendidik dan pembiasaan karakter peserta didik. Melihat apa yang menjadi hasil temuan mengharapkan sekolah dan orang tua mampu memperbaiki dan melakukan kerja sama dapat mendidik nilai integritas pada diri peserta didik. Karena, orang tua merupakan sosial pertama bagi anak, sehingga memiliki kontribusi penting dalam memberntuk karakter seorang anak (Kobandaha, 2019). Hal ini diperkuat dengan pendapat Lickona bahwa sekolah merekrut orang tua sebagai partner dalam mengembangkan nilai moral atau karakter baik yang membantu orang tua elaksanakan peran sebagai pendidik utama anak dan mendukung sekolah 
dalam upaya membelajarakan nilai karakter positif (Lickona, 1991). Selama pandemi kegiatan belajar berupa pengembangan aspek kognitif, afektif dan psikomotorik dilakukan secara penuh dari rumah. Orang tua memiliki peran penting dalam mengarahkan dan memonitoring karakter jujur dan tanggung jawab selama di rumah (Waskito \& Suyitno, 2020). Dalam hal ini sarana yang digunakan yaitu buku pantauan kegiatan nilainilai karakter. Memperkuat peran komite sekolah dan orang tua sebagai pemangku kepentingan pendidikan perlu terus dilakukan dengan baik (Yusuf, 2017).

Adapun yang lainnya kegiatan kolaborasi berbasis masyarakat guna memperkuat karakter integritas di SDN Brosot maupun SD Muh. Wonopeti 1 menggandeng sentral industri batik, bank sampah, pasar, pondok pesantren, dan bank guna mengkaji informasi secara komperhensif menyesuaikan tematik yang ada dalam muatan pelajaran yang dilakukan di satuan pendidikan tersebut. Hal ini sesuai denga penelitian yang dilakukan oleh (Ulya \& Anisah, 2021) menyatakan bahwa PPK perlu pelibatan secara terstruktur antara sekolah, keluarga dan komunitas masyarakat dalam pengintegrasian nilai-nilai karakter termasuk integritas. Satuan pendidikan melakukan kerja sama dengan Lembaga sebagai mitra dalam penguatan pendidikan karakter (PPK, 2017). Langkah kegiatan penguatan pendidikan karakter integritas berbasis masyarakat adalah menentukan tema menyesuaikan tematik pada Kurikulum 2013. Hal ini sejalan dengan pendapat (Banks, Mhunpiew, \& Nathara, 2012) bahwa sekolah harus menyeimbangkan aspek akademik dengan meilihat persoalan yang majemuk pada masyarakat yang nantinya menimbulkan kognitif sosial. Hal ini melatarbelakangi untuk melakukan kunjungan dan melakukan wawancara secara mendalam. Selanjutnya menentukan mitra yang bekerja sama dalam mengembangkan karakter integritas. Menyusun intrumen wawancara yang akan digunakan peserta didik untuk menggali informasi secara mendalam. Selanjutnya melakukan kunjungan kepada mitra tersebut. Berdasarkan hasil pengalaman yang sudah dilakukan di satuan pendidikan dasar kecamatan Galur Kulon Progo misalnya sedang belajar mengenai kebudayaan peserta didik melakukan kunjungan ke sentral batik dan melihat langsung proses pembuatan batik. Selain itu berbekal instrumen wawancara yang sudah dibuat oleh pendidik dengan pemahaman peserta didik dilanjut dengan melaksanakan kegiatan wawancara secara holistik. Keterlibatan komunitas secara luas memiliki manfaat dalam membantu mengidentifikasi dan memperoleh dukungan untuk nilai yang akan diajarkan (Lickona, 1991). Hal ini tentu akan menumbuh kembangkan karakter percaya diri, rasa ingin tahu, mandiri, menghargai karya orang lain, menghargai martabat individu dan bertanggung jawab. Tanggung jawab merupakan kewajiban yang ditanamkan pada diri seseorang atas apa yang telah dilakukannya (Mustari, 2014). Dalam kegiatan kunjungan menemukan kendala seperti pengorganisasian peserta didik dalam kelompok kolaborasi, ada peserta didik yang memerlukan ekstra dalam pengkondisiannya, sehingga dilakukan pendampingan dengan jumlah guru yang memadai. Mengajarkan bersikap berani, rasa ingin tahu yang tinggi, kreativitas, bertanggung jawab sangat diperlukan sejak usia dini. Mengingat anak adalah harta karun negara nasib bangsa ada dipundak generasi selanjutnya (Hartoyo, 2010).

Satuan pendidikan sekolah dasar di Kapenewon Galur melakukan pemanfaatan lingkungan n sebagai sumber belajar dan mengembangkan karakter integritas dengan baik. Pelibatan berbagai komunitas di luar sekolah sebagai penguatan pendidikan karakter berbasis masyarakat yang semakin menginspiratif. Hal ini dapat dilakukan dengan semakin memperkuat kolaborasi dengan LSM, tokoh masyarakat, pengiat seni dan budaya serta mensinergikan program pendidikan karakter sekolah dengan komunitas masyarakat. Selain menggali ilmu dari komunitas masyarakat, fungsi selanjutnya menjadikan masyarakat dalam mengaktualisasi nilai karakter positif dalam kehidupan sehariphari (Hutabarat \& Sumantri , 2019). Kehidupan sosial yang toleran menjadi tolak ukur keberhasilan penguatan pendidikan karakter integritas dalam satuan pendidikan dasar. 

Sumaryati

DOI: https://doi.org/10.31004/edukatif.v4i1.1739

\section{KESIMPULAN}

Penguatan pendidikan karakter integritas berbasis masyarakat pada stuan pendidikan dasar di kecematan Galur Kulon Progo dilakukan dengan menjalin kerja sama yang baik dengan orang tua, komite sekolah dan komunitas masyarakat sekitar. Adapun tahapan dalam merancang program penguatan pendidikan karakter dimulai dari sosialisasi, implementasi, evaluasi dan rencana tindak lanjut. Analisis kebutuhan harus diketahui semua pihak baik sekolah, komite sekolah maupun wali murid agar capaian dan target pendidikan karakter dapat maksimal. Koordinasi yang sifatnya incsdental dan rutin dilakukan guna memonitoring terlaksananya kegiatan karakter di satuan pendidikan dasar tersebut. Pada proses implementasi pendidikan karakter integritas dilakukan secara kolaborasi dengan komunitas di luar sekolah seperti alumni, wali murid, tokoh masyarakat, industi, pasar, bank, pondok pesantren dan sebagainya. Orang tua merupakan bagian penting dalam pelaksanaan pendidikan karakter integritas komunitasi yang secara terstruktur dan intensif dilakukan melalui whatsapp secara pribadi maupun group. Adanya pola kolaborasi dengan berbagai komunitas dan sarana yang mendukung dilakukan guna menumbuh kembangkan karakter integritas seperti kejujuran, bertanggung jawab, cinta akan kebenaran dan mampu menghormati antar individu. Harapannya segala kegiatan yang didesign menjadi sebuah habit dan pembiasan pada diri peserta didik untuk semakin kuat nilai-nilai karakter positif dengan ekosistem yang mendukung.

\section{UCAPAN TERIMA KASIH}

Terima kasih kami ucapkan kepada LPPM Universitas Ahmad Dahlan yang teleh memberikan dukungan telah terselenggaranya penelitian ini. Terima kasih untuk semua pihak yang berkontribusi dalam penelitian ini yaitu UAD, SDN Brosot dan SD Muhammadiyah Wonopeti 1. Semoga hasil penelitian memberikan kontribusi khasnah keilimuan khususnya penguatan pendidikan karakter integritas berbasis masyarakat pada sekolah dasar.

\section{DAFTAR PUSTAKA}

Anshori, I. (2017). Penguatan Pendidikan Karakter Di Madarasah. Halaqa: Islamic Education Journal, 63-74.

Ali, Kristiawan, M., \& Fitriani, Y. (2021). Impementasi Pendidikan Krakter Berbasis Budaya Sekolah. Jurnal Pendidikan Tambusai, 2063-2069.

Auliyairrahmah, A., Djazilan, S., Nafiah, \& Hartatik, S. (2021). Implementasi Pendidikan Karakter Integritas Sub Nilai Kejujuran Melalui Program Kantin Kejujuran Di Sekolah Dasar. Edukatif: Jurnal Ilmu Pendidikan Research \& Learning In Education, 3565 - 3578.

Banks, J., Mhunpiew, \& Nathara. (2012). Authentic Leadership, Social Cognitive Theory, And Character Education: The Transforming Of Theories Into Practices. Us-China Education Review, 1002-1006.

Dewantara, K. H. (2011). Karya Ki Hadjae Dewantara Bagian Pertama Pendidikan. Yogyakarta: Majekis Luhur Persatuan Tamansiswa.

Fraenkel, J. R. (1977). How To Teach About Values: An Analytical Approach, Enlewood. Nj: Prentice-Hall.

Hartoyo, H. A. (2010). Potensi Pembinaan Karakter Berbasis Budaya Masyarakat. Jurnal Pendidikan Sosiologi Dan Humaniora, 20-30.

Hutabarat, P. K., \& Sumantri , E. (2019). Implementasi Penguatan Pendidikan Karakter Berbasis Masyarakat Dalam Meningkatkan Kesadaran Sikap Peduli Sosial Peserta Didik (Studi Kasus Di Sma Kartika Xix-12 Bandung). Reaktualisasi Konsep Kewarganegaraan Indonesia (Pp. 157-170). Medan: Jurusan Pendidikan Pancasila Dan Kewarganegaraan Fakultas Ilmu Sosial Universitas Negeri Medan. 
Kurniawan, M. I. (2015). Tri Pusat Pendidikan Sebagai Sarana Pendidikan Karakter Anak Sekolah Dasar. Journal Pedagogia, 41-49.

Kurniawan, W. M., \& Kusumawardana , A. S. (2020). Strategi Penguatan Pendidikan Karakter Melalui Budaya Sekolah Di Sma Negeri 7 Malang. Seminar Nasional Virtual Pendidikan Kewarganegaraan 2020 (Pp. 776-785). Surakarta: Laboratorium Program Studi Ppkn, Fkip, Universitas Sebelas Maret.

Kobandaha, I. M. (2019). Keluarga Sebagai Basis Pendidikan Karakter. Jurnal Ilmiah Dikdaktika.

Komara, E. (2018). Penguatan Pendidikan Karakter Dan Pembelajaran Abad 21. Sipatahoenan: South-East Asian Journal For Youth, Sports \& Health Education, 17-26.

Lickona, T. (1991). Educating For Character: How Our Schools Can Teach Respect And Responsibility. New York: Bantam Books.

Mustari, M. (2014). Nilai Karakter Refleksi Untuk Pendidikan. Jakarta: Raja Grafindo.

Moleong, L. J. (2007). Metodologi Penelitian Kualitatif. Bandung: Pt Remaja Rosdakarya Offset.

National Education Sociaty. (N.D.). An Educator's Guide To The "Four Cs": Preparing 21st Century Students For A Global Society.

Ppk, T. (2017). Konsep Dan Pedoman Pengauatan Pendidikan Karakter. Jakarta: Kemendikbud.

Suyadi, I. (2013). Strategi Pembelajaran Pendidikan Karakter. Bandung: Remaja Rosdakarya.

Sriwilujeng, D. (2017). Panduan Implementasi Pendidikan Karakter. Jakarta: Esensi Erlangga Group.

Ulya, V. F., \& Anisah, Z. (2021). Pembentukan Nilai Karakter Integritas Melalui Gerakan Literasi Sekolah Pada Anak Mi/Sd. Premiere : Journal Of Islamic Elementary Education, 43-56.

Waskito, A. P., \& Suyitno. (2020). Implementasi Penguatan Karakter Nilai Integritas Melalui Buku Kegiaatan Hariaan Siswa Sd Muhammadiyah Kadisoka Yogyakarta. Fundamental Pendidikan Dasar, 127-138.

Widodo, H. (2019). Penguatan Pendidikan Karakter Di Sd Muhammadiyah Macanan Sleman Yogyakarta. Lentera Pendididikan Jurnal Ilmu Tarbiyah Dan Keguruan, 40-51.

Wuryandani, W., Maftuh, B., Sapriya, \& Budimansyah, D. (2014). Pendidikan Karakter Disiplin Di Sekolah Dasar. Cakrawala Pendidikan Jurnal Ilmiah Pendidikan, 286-295.

Yusuf, M. (2017). Pendidikan Karakter Menuju Generasi Emas 2045. In M. Yusuf, Inovasi Pendidikan (Pp. 9 16). Salatiga: Widya Sari Press.

Yetri, \& Firdaos, R. (2017). Penguatan Pendidikan Karakter Berbasis Masyarakat Pada Sekolah Menengah Pertama Negeri (Smpn) Di Kabupaten Tulang Bawang Provinsi Lampung . Al-Tadzkiyyah: Jurnal Pendidikan Islam, Volume 8,No. Ii, 267-279.

Zubaedi. (2011). Desain Pendidikan Karakter. Jakarta: Kencana. 